\title{
Systematic review of factors influencing patient and practitioner delay in diagnosis of upper gastrointestinal cancer
}

\author{
S Macdonald', U Macleod', NC Campbell' ${ }^{2}$ D Weller ${ }^{3}$ and E Mitchell ${ }^{*, 4}$ \\ 'General Practice and Primary Care, Division of Community Based Sciences, University of Glasgow, I Horselethill Road, Glasgow GI 2 9LX, UK; ${ }^{2}$ General \\ Practice and Primary Care, University of Aberdeen, Foresterhill Health Centre, Westburn Road, Aberdeen AB25 2AY, UK; ${ }^{3}$ Community Health Sciences \\ (General Practice), University of Edinburgh, 20 West Richmond Street, Edinburgh EH8 9DX, UK; ${ }^{4}$ School of Health and Social Care, Glasgow Caledonian \\ University, City Campus, Cowcaddens Road, Glasgow G4 OBA, UK
}

As knowledge on the causation of cancers advances and new treatments are developed, early recognition and accurate diagnosis becomes increasingly important. This review focused on identifying factors influencing patient and primary care practitioner delay for upper gastrointestinal cancer. A systematic methodology was applied, including extensive searches of the literature published from 1970 to 2003, systematic data extraction, quality assessment and narrative data synthesis. Included studies were those evaluating factors associated with the time interval between a patient first noticing a cancer symptom and presenting to primary care, between a patient first presenting to primary care and being referred to secondary care, or describing an intervention designed to reduce those intervals. Twenty-five studies were included in the review. Studies reporting delay intervals demonstrated that the patient phase of delay was greater than the practitioner phase, whilst patient-related research suggests that recognition of symptom seriousness is more important than recognition of the presence of the symptom. The main factors related to practitioner delay were misdiagnosis, application and interpretation of tests, and the confounding effect of existing disease. Greater understanding of patient factors is required, along with evaluation of interventions to ensure appropriate diagnosis, examination and investigation.

British Journal of Cancer (2006) 94, 1272 - 1280. doi:I0.1038/sj.bjc.6603089 www.bjcancer.com

Published online II April 2006

(c) 2006 Cancer Research UK

Keywords: delay; diagnosis; systematic review; upper gastrointestinal

Achieving a reduction in deaths from cancer is a worldwide healthcare priority. As new knowledge on the causation of cancers is discovered, new treatments developed and the search for cures continues, early recognition and accurate diagnosis becomes increasingly important. This is particularly relevant in the context of primary care, where many patients present with symptoms suggestive of cancer, but where the outcome of the diagnostic process is the exclusion of cancer in the majority of cases.

Detecting and diagnosing cancer when it is at an early stage improves prognosis for many cancers (Love, 1991; Ponten et al, 1995; Richards et al, 1999; Summerton, 1999). Previous work on delay has shown that this can occur at three phases in the time from initial symptom to diagnosis. Firstly, there is the interval between first noticing a symptom and first consulting a doctor (patient delay); secondly, the interval between first consultation with a doctor and referral (practitioner delay); and finally, the time between referral and diagnosis (hospital delay) (Nichols et al, 1981). If a reduction in deaths from cancer is to be achieved, a greater understanding of the reasons for late and delayed diagnosis in patients with potential cancer symptoms is required. This is a significant challenge, especially for primary care, which is usually the patient's first contact with the health services and conse-

*Correspondence: Dr E Mitchell; E-mail: liz.mitchell@gcal.ac.uk Received I November 2005; revised 8 March 2006; accepted 13 March 2006; published online II April 2006 quently, the area to which the first two phases of delay are particularly applicable.

We conducted a systematic review of the factors that influence patient and practitioner delay (Macdonald et al, 2004) for all adult cancers for which the UK Department of Health (DoH) has published referral guidelines, with the exception of breast cancer (Department of Health, 2000; National Institute for Health and Clinical Excellence, 2005). This paper outlines the methods used in the review and presents results for upper gastrointestinal (GI) cancers.

\section{MATERIALS AND METHODS}

A worldwide review of the literature from 1970 to November 2003 was conducted. Extensive searches of Medline, EMBASE, CINAHL, PsycINFO, ISI Science Citation Index, ISI Social Sciences Citation Index and the International Bibliography of the Social Sciences were carried out. Supplementary searches of Proceedings First and Web of Science Proceedings were conducted to provide relevant unpublished research. The Effective Practice and Organisation of Care, Consumers and Communication and cancer-related Cochrane Collaborative Review Groups were asked for details of any potentially relevant studies. The National Research Register and the DoH Research Findings electronic Register (ReFeR) were accessed online for details of ongoing or recently completed projects, and the Medical Research Council, Cancer Research UK and the Chief Scientist Office of the Scottish Executive Health 
Department were contacted for details of relevant work. A database of almost 300 UK contacts with a particular interest in cancer was established, representing Scottish and English health authorities, cancer networks and cancer leads. A list of international contacts was also compiled, including similar organisations in North America, Europe, Australia and New Zealand. Requests were made to authors active in the field for studies-in-progress and unpublished work. Citations in literature reviews and articles obtained were also reviewed, as were references provided by colleagues.

\section{Study selection}

Studies in any language and of any design were considered. Studies were selected if they focused on adult cancer and (a) the participants were individuals/groups of patients or primary care practitioners and (b) they evaluated factors associated with the time interval between a patient first noticing a cancer symptom and first presenting to a primary health-care provider, or described an intervention designed to reduce that interval or (c) they evaluated factors associated with the time interval between the patient first presenting to primary care and being referred to secondary care, or described an intervention designed to reduce that interval. We were also interested in identifying the factors associated with patient and provider behaviour, in relation to their impact on patient help-seeking or on practitioner referral, and studies that determined provider attitudes or behaviour towards referral of patients with cancer were also included, as were those that determined patient attitudes towards cancer awareness and presentation behaviour. Studies evaluating delay from presentation to treatment were not excluded until they had been reviewed to ensure that they did not differentiate between possible stages within the delay cycle. Studies that simply assessed the outcome of delay in terms of diagnosis, treatment or patient outcomes were excluded, as were those assessing costs of interventions or validity of referral decisions.

All references identified were independently assessed by two reviewers (SM, UM). Abstracts were reviewed and full texts of studies not excluded at this stage were retrieved for detailed evaluation. Discrepancies were independently validated by a third reviewer (EM). All potentially relevant studies were independently read and, if included in the review, independently rated by the same two reviewers. Where differences of opinion occurred, papers were read by the third reviewer and findings discussed until a consensus was reached.

\section{Strength of evidence}

Methodological quality of experimental studies (randomised controlled trial, clinical trials, controlled before and after studies) was assessed for sample formation, baseline differences between groups, unit of allocation to groups, measures of outcome and follow-up (Appendix A1). Owing to the lack of controlled trials in this field, a method of scoring descriptive studies (cross-sectional, cohort, case-control, before and after studies) was also used, allowing interpretation of useful papers that would be discarded by strict adherence to Cochrane standards. Each study was scored on six criteria relevant to its design (e.g. case-control was assessed for a clear research question, source of cases/controls, clear inclusion/exclusion criteria, sampling method and comparability of the groups) (Appendix B1). Similar use of these systems has been described elsewhere (Mitchell and Sullivan, 2001).

However, many papers in this review used methodologies that did not lend themselves to the scoring systems outlined. Several included every patient attending a particular clinic and most collected data using either medical records review or structured interviews with patients. We therefore assessed each included study for the strength of its evidence in relation to the factors reported as leading to increased or decreased delay. Assessment of studies that had already been rated using the systems outlined above was based on those previous scores. Evidence was rated as 'strong' if a paper had an adequate sample size, used a rigorous methodology to ascertain data (i.e. not open to selection bias) and reported statistically significant differences in relation to the factors identified (or used appropriate analytic techniques if qualitative). Evidence was rated as 'moderate' if a paper had an adequate sample size, reported significant differences but used a less rigorous methodology to ascertain data, or had an adequate sample size, used a rigorous methodology to ascertain data but used comparative analysis or reported only relevant descriptive statistics, without performing statistical testing of differences. Finally, evidence was rated as 'insufficient' if a paper had an unclear or inappropriate method of ascertaining data and insufficient analysis. If a study inferred results, the strength of its evidence was reduced, for example, strong became moderate.

Narrative synthesis of findings was then carried out to identify key concepts and themes that were shared across individual studies. Textual information on cancer group, delay aspects studied and differences resulting from any intervention was also recorded.

\section{RESULTS}

The search strategy identified 6441 abstracts, which were reviewed to determine their suitability for inclusion (Figure 1). Full reprints were obtained for the 104 articles that met the inclusion criteria and these were evaluated further. Kappa co-efficient for inter-rater agreement beyond chance was 0.5 . Twenty-five papers were included in the review.

The majority of included studies $(n=18)$ were conducted in western Europe, almost half of these in the UK. None of the studies employed a controlled trial methodology. Most involved medical records review and/or structured interviews with patients; seven studies used mixed methods of data collection. More than half of the papers studied patient and practitioner delay factors, six studied patient factors only and six studied practitioner factors only. Prominence was given to stomach, followed by oesophagus, pancreas and small intestine. Nine papers were assessed as

\section{Potentially relevant articles identified and screened for retrieval $(n=6441)$}

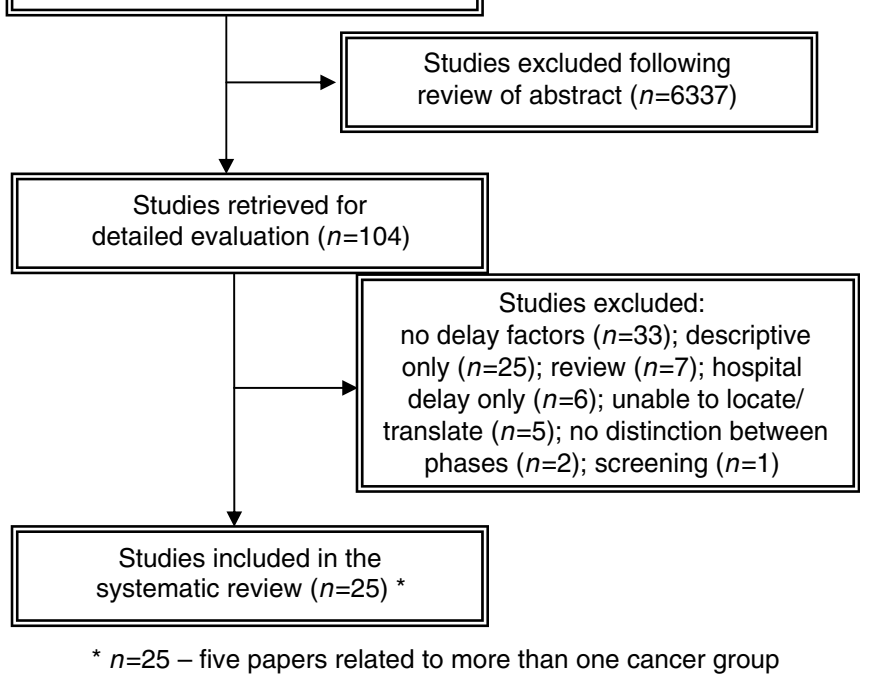

Figure I Flow of studies into the review. 
providing strong evidence, nine provided moderate evidence and seven provided insufficient evidence.

In general, studies were relatively small in size, involving between 30 and 2500 participants (mean 383; median 133). Only two of the studies included practitioners as participants. In the majority, the population under study was identified from secondary care $(n=21)$. In seven studies participants were hospital in-patients, in four they were outpatient attenders and in two others both in-patients and outpatients were involved. A further seven studies identified patients from hospital records. One study involved members of the public, and another patients participating in an existing trial. Only three studies recruited from primary care. The period under study ranged from 1 week to 30 years.

\section{Delay intervals}

Twenty studies reported length of delay, either from patient recognition of symptoms to first presentation $(n=17)$ or from presentation to referral or diagnosis $(n=13)$. Median patient delay ranged from 2 weeks to 7.5 months (Bedikan et al, 1979; Mikulin and Hardcastle, 1987; Zilling et al, 1990; Haugstvedt et al, 1991; Wile et al, 1993; Porta et al, 1996; Martin et al, 1997; Mariscal et al, 2001; Irving et al, 2002; Look et al, 2003) and practitioner delay from zero to just under 9 months (Mikulin and Hardcastle, 1987; Zilling et al, 1990; Haugstvedt et al, 1991; Jones and Dudgeon, 1992; Martin et al, 1997; Mariscal et al, 2001; Irving et al, 2002; Look et al, 2003).

\section{Factors influencing patient delay}

Nineteen papers considered factors that influenced patient delay in presentation. Thirteen identified factors that increased delay and 13 identified factors that decreased delay (Table 1).
Symptoms, patient's interpretation of them and the associated impact on delay emerged as a major theme across studies. Heightened awareness of symptoms provoked more prompt presentation to a practitioner (Ojala et al, 1982; Delaney, 1998; Gullo et al, 2001), whereas lack of awareness resulted in delay (Nagao and Takahashi, 1979; Mikulin and Hardcastle, 1987; Arvanitakis et al, 1992; Porta et al, 1996; Rothwell et al, 1997; Ibingira, 2001). Similarly, the perceived significance of symptoms was a key factor, but the precise nature of its effect on delay was inconclusive. Many patients consulted more quickly when their symptoms were more serious or were perceived to be more serious, including the presence of pain or bleeding (Hackett et al, 1973; MacAdam, 1979; Ojala et al, 1982; Mikulin and Hardcastle, 1987; Maglinte et al, 1991; Grannell et al, 2001; Mariscal et al, 2001). For others, however, experiencing pain increased their delay (Hackett et al, 1973; Ibingira, 2001; Look et al, 2003), as did weight loss (Haugstvedt et al, 1991). The presence of multiple symptoms or comorbidity resulted in more prompt presentation (Porta et al, 1996; Mariscal et al, 2001).

The fear associated with recognising potential cancer symptoms was found to have both a positive (Delaney, 1998) and negative (Hackett et al, 1973) impact on presentation behaviour. Although the associated worry could be beneficial in reducing delay, we also found evidence that patients were less likely to consult when they were afraid that their symptoms were indicative of cancer (Mikulin and Hardcastle, 1987) or meant that they would have to undergo tests (Delaney, 1998). Patients who redefined their symptoms, perhaps in response to that fear, delayed longer (Delaney, 1998).

There was some evidence to suggest that the setting of first presentation impacts on delay, with those who presented first to hospital doing so after shorter symptom duration (Wile et al, 1993; Mariscal et al, 2001) (Table 2).

A number of studies considered the relationship between certain patient characteristics and presentation behaviour. Ethnicity was

Table I Main delay factors and assessment of evidence

\begin{tabular}{|c|c|c|c|c|c|}
\hline & $\begin{array}{l}\text { No. of studies } \\
\text { (subjects) }\end{array}$ & Supported (studies) & $\begin{array}{l}\text { Not supported } \\
\text { (studies) }\end{array}$ & No impact (studies) & $\begin{array}{l}\text { Overall assessment } \\
\text { /conclusion }\end{array}$ \\
\hline \multicolumn{6}{|l|}{ Increases patient delay } \\
\hline $\begin{array}{l}\text { Non-recognition of symptom } \\
\text { seriousness }\end{array}$ & $9(1840)$ & $2 S, 3 M, 4 I$ & - & - & Increases delay \\
\hline Cancer site - stomach & $2(7 \mid 3)$ & IS, IM & - & - & Increases delay \\
\hline Lower socio-economic status & $4(979)$ & $2 \mathrm{~S}, 1 \mathrm{M}$ & - & IM & Increases delay \\
\hline Comorbidity & $2(400)$ & - & $2 S$ & - & Reduces delay \\
\hline First presenting to hospital & $2(266)$ & - & 25 & - & Reduces delay \\
\hline Male sex & $5(797)$ & 11 & IS & IS, 2M & No impact on delay \\
\hline Fear & $3(|27|)^{\mathrm{a}}$ & $2 \mathrm{~S}, \mathrm{IM}$ & $2 S$ & - & Inconclusive \\
\hline Experiencing pain & $7(1169)$ & IS, IM, II & IS, 3M & - & Inconclusive \\
\hline Older age & $7(800)$ & IS, IM & $1 \mathrm{~S}, 2 \mathrm{M}$ & IS, IM & Inconclusive \\
\hline Lower education & $2(400)$ & is & is & - & Inconclusive \\
\hline Family history & $3(777)$ & IS & IS & is & Inconclusive \\
\hline \multicolumn{6}{|l|}{ Increases practitioner delay } \\
\hline Initial misdiagnosis & $6(3556)$ & $2 M, 4 I$ & - & - & Increases delay \\
\hline Acid suppression treatment & $3(316)$ & $1 \mathrm{~S}, 2 \mathrm{M}$ & - & - & Increases delay \\
\hline Inappropriate/inaccurate tests & $3(226)$ & IS, 2M & - & - & Increases delay \\
\hline Previous negative test result & $2(94)$ & IS, IM & - & - & Increases delay \\
\hline Cancer site - oesophagus & $2(1580)$ & IM, II & - & - & Increases delay \\
\hline Female patient & $2(1215)$ & IS, IM & - & - & Increases delay \\
\hline Older patient age & | (83) & - & IM & - & Reduces delay \\
\hline Lower patient socio-economic status & I (83) & - & IM & - & Reduces delay \\
\hline Use of referral guidelines & $1(90)$ & - & is & - & Reduces delay \\
\hline Frequent patient attendance & $2(265)$ & 11 & - & IM & Inconclusive \\
\hline Comorbidity & $2(267)$ & is & IS & - & Inconclusive \\
\hline Use of rapid access endoscopy & $2(821)$ & IS & II & - & Inconclusive \\
\hline
\end{tabular}

apaper reports conflicting evidence (i.e. which both supports and refutes the factor as a cause of delay). $\mathrm{S}=$ strong evidence; $\mathrm{M}=$ moderate evidence; I= insufficient evidence (based on the methodological adequacy of the study). 
Table 2 Patient-associated delay factors

\begin{tabular}{|c|c|c|c|c|c|c|c|c|}
\hline Author(s) & Location & Study type & Participants & Cancer site & $\begin{array}{l}\text { Factors that increase } \\
\text { delay }\end{array}$ & $\begin{array}{l}\text { Factors that decrease } \\
\text { delay }\end{array}$ & $\begin{array}{l}\text { No impact on } \\
\text { delay }\end{array}$ & $\begin{array}{l}\text { Strength of } \\
\text { evidence }\end{array}$ \\
\hline Hackett et al (1973) & $\begin{array}{l}\text { Massachusetts, } \\
\text { USA }\end{array}$ & $\begin{array}{l}\text { Prospective } \\
\text { observational }\end{array}$ & $\begin{array}{l}563 \text { patients (aged I7-91; } \\
\text { mean } 62 ; 46 \% \text { men, } \\
54 \% \text { women), } \\
6 \% \text { with stomach cancer }\end{array}$ & Stomach & $\begin{array}{l}\text { Symptom type - pain; } \\
\text { cancer site - stomach; } \\
\text { social class - lower; worry } \\
\text { over health; family history }\end{array}$ & $\begin{array}{l}\text { Worry; incapacitated by } \\
\text { symptoms; } \\
\text { acknowledgment of cancer }\end{array}$ & & Strong \\
\hline Bedikan et al (1979) & Texas, USA & $\begin{array}{l}\text { Retrospective } \\
\text { observational }\end{array}$ & $\begin{array}{l}73 \text { patients (aged }<40 \\
48 \% \text { men, } 52 \% \text { women) }\end{array}$ & Stomach & & Age - older & & Moderate \\
\hline $\begin{array}{l}\text { Nagao and Takahashi } \\
\text { (1979) }\end{array}$ & Japan & $\begin{array}{l}\text { Retrospective } \\
\text { observational }\end{array}$ & 536 patients & Stomach & $\begin{array}{l}\text { Non-recognition of } \\
\text { symptom seriousness }^{\mathrm{a}}\end{array}$ & & & Insufficient \\
\hline MacAdam (1979) & England & $\begin{array}{l}\text { Prospective } \\
\text { observational }\end{array}$ & $\begin{array}{l}\text { I } 50 \text { patients ( } 21 \% \text { with } \\
\text { stomach cancer), } \\
\text { I05 GPs }\end{array}$ & Stomach & Cancer site - stomach & $\begin{array}{l}\text { Symptom type - } \\
\text { abdominal pain, bleeding }\end{array}$ & $\begin{array}{l}\text { Socio-economic } \\
\text { status; age; sex; } \\
\text { social isolation; } \\
\text { frequency of } \\
\text { consulting }\end{array}$ & Moderate \\
\hline Ojala et al (1982) & Finland & $\begin{array}{l}\text { Retrospective } \\
\text { observational }\end{array}$ & $\begin{array}{l}162 \text { patients (aged } \\
38-82, \text { mean } 63 ; \\
59 \% \text { men, } 41 \% \text { women) }\end{array}$ & Oesophagus & & $\begin{array}{l}\text { Patient awareness; } \\
\text { symptom type - } \\
\text { dysphagia }^{\text {a }}\end{array}$ & & Insufficient \\
\hline $\begin{array}{l}\text { Mikulin and Hardcastle } \\
\text { (1987) }\end{array}$ & England & $\begin{array}{l}\text { Prospective } \\
\text { observational }\end{array}$ & $\begin{array}{l}83 \text { patients (mean 7I; } \\
64 \% \text { men, 36\% women) }\end{array}$ & Stomach & $\begin{array}{l}\text { Non-recognition of } \\
\text { symptom seriousness; } \\
\text { symptom type - no pain; } \\
\text { fear; age - older; social } \\
\text { class - lower }\end{array}$ & Age - younger & Sex & Moderate \\
\hline Zilling et al (1990) & Sweden & $\begin{array}{l}\text { Prospective } \\
\text { observational }\end{array}$ & $\begin{array}{l}50 \text { patients (aged } 31-85 \\
\text { mean } 68 ; 74 \% \text { men, } \\
26 \% \text { women) }\end{array}$ & Stomach & Age - younger & & & Strong \\
\hline $\begin{array}{l}\text { Haugstvedt et al } \\
(1991)\end{array}$ & Norway & $\begin{array}{l}\text { Prospective } \\
\text { observational }\end{array}$ & | 165 patients & Stomach & $\begin{array}{l}\text { Symptom type - weight } \\
\text { loss }\end{array}$ & $\begin{array}{l}\text { Referral to university } \\
\text { hospital }\end{array}$ & & Moderate \\
\hline Maglinte et al (1991) & Indiana, USA & $\begin{array}{l}\text { Retrospective } \\
\text { observational }\end{array}$ & $\begin{array}{l}77 \text { patients (aged } 30-89 \\
\text { mean } 59 ; 64 \% \text { men, } \\
36 \% \text { women }\end{array}$ & $\begin{array}{l}\text { Small } \\
\text { intestine }\end{array}$ & & $\begin{array}{l}\text { Symptom type - pain, } \\
\text { bleeding }\end{array}$ & & Moderate \\
\hline $\begin{array}{l}\text { Arvanitakis et al } \\
\text { (1992) }\end{array}$ & Greece & Observational & $\begin{array}{l}100 \text { patients (aged } \\
40-90 ; 64 \% \text { men, } \\
36 \% \text { women) }\end{array}$ & Stomach & $\begin{array}{l}\text { Non-recognition of } \\
\text { symptom seriousness }\end{array}$ & & & Insufficient \\
\hline Wile et al (1993) & $\begin{array}{l}\text { California, } \\
\text { USA }\end{array}$ & $\begin{array}{l}\text { Retrospective } \\
\text { observational }\end{array}$ & $\begin{array}{l}49 \text { patients (median } 57 \text {; } \\
45 \% \text { men, } 55 \% \text { women) }\end{array}$ & Stomach & & $\begin{array}{l}\text { First presenting at hospital; } \\
\text { ethnicity - minority groups }\end{array}$ & & Strong \\
\hline Porta et al (1996) & Spain & $\begin{array}{l}\text { Prospective } \\
\text { observational }\end{array}$ & $\begin{array}{l}\text { I } 83 \text { patients (mean } 67 ; \\
66 \% \text { men, } 34 \% \text { women) }\end{array}$ & $\begin{array}{l}\text { Oesophagus, } \\
\text { stomach, } \\
\text { duodenum }\end{array}$ & $\begin{array}{l}\text { Age - older; sex - male; } \\
\text { illiteracy; social class - } \\
\text { lower; unemployment; } \\
\text { non-recognition of } \\
\text { symptom seriousness }\end{array}$ & $\begin{array}{l}\text { Age - younger; } \\
\text { comorbidity; recognition of } \\
\text { symptom seriousness }\end{array}$ & $\begin{array}{l}\text { Marital status; } \\
\text { family history }\end{array}$ & Strong \\
\hline Rothwell et al (1997) & Ireland & $\begin{array}{l}\text { Prospective } \\
\text { observational }\end{array}$ & $\begin{array}{l}\text { I00 patients (aged } 37-83 \\
\text { median } 69 ; 70 \% \text { men, } \\
30 \% \text { women) }\end{array}$ & Oesophagus & $\begin{array}{l}\text { Non-recognition of } \\
\text { symptom seriousness }\end{array}$ & & & Moderate \\
\hline Delaney (1998) & England & $\begin{array}{l}\text { Qualitative } \\
\text { interviews }\end{array}$ & $\begin{array}{l}31 \text { patients with dyspepsia } \\
\text { (aged } 50+, \text { mean } 64 ; \\
52 \% \text { men, } 48 \% \text { women) }\end{array}$ & Stomach & $\begin{array}{l}\text { Fear of investigation; } \\
\text { symptom re-definition; } \\
\text { fatalism }\end{array}$ & $\begin{array}{l}\text { Recognition of symptom } \\
\text { seriousness; personal or } \\
\text { family history; fear of } \\
\text { cancer }\end{array}$ & & Strong \\
\hline Mariscal et al (200I) & Spain & $\begin{array}{l}\text { Prospective } \\
\text { observational }\end{array}$ & $\begin{array}{l}217 \text { patients (aged } 59-74 \text {, } \\
\text { mean } 65 ; 59 \% \text { men, } \\
41 \% \text { women), } 27 \% \text { with } \\
\text { upper } \mathrm{Gl} \text { cancer }\end{array}$ & $\begin{array}{l}\text { Oesophagus, } \\
\text { stomach }\end{array}$ & Education level - higher & $\begin{array}{l}\text { Comorbidity; symptom } \\
\text { type - pain, bleeding; first } \\
\text { presenting at hospital; } \\
\text { multiple symptoms }\end{array}$ & $\begin{array}{l}\text { Age; sex; } \\
\text { availability of } \\
\text { vehicle }\end{array}$ & Strong \\
\hline Gullo et al (200I) & Italy & Case-control & $\begin{array}{l}305 \text { patients (aged } 30-75 \text {, } \\
\text { mean } 61 ; 62 \% \text { men, } \\
38 \% \text { women) and } 305 \\
\text { matched controls }\end{array}$ & Pancreas & & Symptom recognition ${ }^{\mathrm{a}}$ & & Moderate \\
\hline |bingira (200|) & Uganda & $\begin{array}{l}\text { Prospective } \\
\text { observational }\end{array}$ & $\begin{array}{l}35 \text { patients (aged } 34-78 \\
77 \% \text { men, } 23 \% \text { women) }\end{array}$ & Stomach & $\begin{array}{l}\text { Non-recognition of } \\
\text { symptom seriousness; } \\
\text { symptom type - pain; acid } \\
\text { suppression treatment }\end{array}$ & & & Insufficient \\
\hline Grannell et al (200I) & Ireland & Cross-sectional & $\begin{array}{l}\text { I } 64 \text { members of the public } \\
\text { ( } 93 \text { aged <45, } 71 \text { aged } \\
45+; 51 \% \text { men, } \\
49 \% \text { women) }\end{array}$ & Oesophagus & Sex - female & $\begin{array}{l}\text { Increased awareness - } \\
\text { dysphagia }^{\text {a }}\end{array}$ & & Insufficient \\
\hline Look et al (2003) & Singapore & $\begin{array}{l}\text { Retrospective } \\
\text { observational }\end{array}$ & $\begin{array}{l}44 \text { patients (aged } 36-83 \text {, } \\
\text { mean } 67 ; 70 \% \text { men, } \\
30 \% \text { women) }\end{array}$ & Stomach & $\begin{array}{l}\text { Age - younger; symptom } \\
\text { type - pain }\end{array}$ & & & Moderate \\
\hline
\end{tabular}

Abbreviation: $\mathrm{Gl}=$ gastrointestinal. ${ }^{\text {a }}$ Study infers findings. 
associated with reduced delay (Wile et al, 1993), while lower socioeconomic status (Hackett et al, 1973; Mikulin and Hardcastle, 1987; Porta et al, 1996) was associated with increased delay. By and large, sex had no impact on delay (MacAdam, 1979; Mikulin and Hardcastle, 1987; Porta et al, 1996; Mariscal et al, 2001), whereas the evidence presented for education level (Porta et al, 1996; Mariscal et al, 2001) and age was inconclusive (Bedikan et al, 1979; MacAdam, 1979; Mikulin and Hardcastle, 1987; Zilling et al, 1990; Porta et al, 1996; Mariscal et al, 2001; Look et al, 2003) (Table 2).

\section{Factors influencing practitioner delay}

Nineteen studies considered factors that influenced practitioner delay in referral. Seventeen identified factors that increased delay and six identified factors that decreased delay (Table 1).

Delay in referral was primarily related to initial misdiagnosis of a common symptom or failure to make a diagnosis at the initial encounter with the patient (Bedikan et al, 1979; Nagao and Takahashi, 1979; Ojala et al, 1982; Hallissey et al, 1990; Arvanitakis et al, 1992; Rothwell et al, 1997). Moreover, referral was likely to be delayed if the patient was being treated for a benign condition, particularly with acid suppression (Mikulin and Hardcastle, 1987; Rothwell et al, 1997; Bramble et al, 2000). Inappropriate application of tests, inaccurate test results and previous receipt of negative test results were additional causes of delay (Zilling et al, 1990; Maglinte et al, 1991; Wile et al, 1993; Rothwell et al, 1997; Look et al, 2003) (Table 3).

Some of the more recent studies evaluated policy initiatives aimed at tackling referral delays. Where a rapid access endoscopy service was available, patients were found to experience less delay in referral (Martin et al, 1997; Manes et al, 2002), albeit with the caveat that inappropriate use of such a service could actually contribute to delay (Manes et al, 2002). Similarly, the introduction of the DoH cancer referral guidelines was found to reduce delay (Irving et al, 2002).

Evaluation of the impact of tumour site on delay demonstrated that patients with oesophageal cancer were more likely to experience delayed referral than patients with stomach cancer (Martin et al, 1997). In addition, patients with any upper GI cancer, regardless of site, were delayed more than patients with colorectal or other cancers (MacAdam, 1979; Jones and Dudgeon, 1992).

Only a limited number of patient characteristics were considered in relation to practitioner delay. Male patients (Zilling et al, 1990; Haugstvedt et al, 1991), older patients (Mikulin and Hardcastle, 1987) and patients from lower socio-economic groups (Mikulin and Hardcastle, 1987) were less likely to experience delayed referral (Table 3).

\section{DISCUSSION}

In 1938, the American Journal of Cancer published a paper by Pack and Gallo (1938) entitled 'The culpability for delay in the treatment of cancer'. This was one of the first papers to study delay as it has been considered in this review. Sadly, almost 70 years later, we echo their findings. Analysis of the studies included in this review shows that there are associations between at least 14 different factors and delay. Five of these concerned delay by patients; nine concerned delay by practitioners. The main themes to emerge related to recognition and interpretation of symptoms, patient history, patient characteristics and health-care factors.

\section{Quality of studies}

This was an extensive and comprehensive review of the world literature; yet, although we identified an abundance of descriptive work, few evaluative studies have been carried out. Great variation in study design and quality precluded a meta-analysis; rather, we graded study evidence by the robustness of its methodology and analysis, allowing us to weight each study appropriately in our overall assessment of delay-related factors. Any critique of this type can only be based on the information that has been reported and in many cases this was incomplete and unclear. However, more recent studies tended to rate more highly, possibly a reflection of the increased reporting standards now required by journals. Although the majority of studies used a non-traditional design and conducted records review or structured patient interview, they were on the whole methodologically rigorous. Nine of the 25 studies provided strong evidence and a further nine moderate evidence. Only seven studies were graded as insufficient.

\section{Delay intervals}

The majority of included studies reported length of delay, and although more than half obtained these data from abstraction of hospital records, there was no uniform approach to the provision of this information. Consequently, it was not possible to determine definitive delay intervals. Nonetheless, the available data do demonstrate extreme delay in both the patient and practitioner phases. What is also clear is that delay intervals are not decreasing; those recorded in the last 5 years are as lengthy as those recorded 20 years ago. Despite this, we identified no intervention studies related to upper GI cancers.

\section{Symptom recognition}

The results of this review suggest that what is important in terms of patient delay is recognition of the seriousness of a symptom, and not simply recognition of the presence of the symptom itself. Patients who have significant symptoms, and perceive them to be so, may present promptly. Equally, they may delay through fear. The catalyst for presentation was often when a symptom became debilitating or hampered normal activities, but the precise influence of this was unclear. Experiencing pain, for example, was found to both reduce and increase patient delay. An obvious difficulty, particularly with GI cancers, is that common symptoms can be attributable to benign disease. Consequently, patients may not present immediately. This poses a challenge for health educators, who must strike a balance between emphasising the potentially significant nature of symptoms, regardless of their commonality, and creating unnecessary fear.

Similarly, symptom recognition and interpretation were no less important for practitioners. Delays following initial patient presentation were often the result of misdiagnosis of benign disease or of adopting a wait and see approach following the first encounter with the patient.

\section{Patient history}

As could perhaps be predicted, patients' previous experience played a role in current decisions to consult with cancer symptoms. Perceptions of symptom seriousness were often based on a personal or family history of similar symptoms and this could have a two-fold effect. Such knowledge prompted some patients to present sooner rather than later; however, for some, the fear that symptoms were indicative of cancer resulted in delayed consultation. Patients who redefined their symptoms, perhaps in relation to that fear or on the basis of prior experience, delayed longer. Similarly, patients who had previously been treated for benign disease delayed longer. Conversely, patients with comorbidity presented more quickly, possibly as a consequence of regular attendance for other conditions, and the resultant ease with which new symptoms could be discussed.

In addition, patient history was a significant factor in relation to practitioner behaviour. Although research relating to the impact of 
Table 3 Practitioner-associated delay factors

\begin{tabular}{|c|c|c|c|c|c|c|c|c|}
\hline Author(s) & Location & Study type & Participants & Cancer site & $\begin{array}{l}\text { Factors that increase } \\
\text { delay }\end{array}$ & $\begin{array}{l}\text { Factors that decrease } \\
\text { delay }\end{array}$ & $\begin{array}{l}\text { No impact } \\
\text { on delay }\end{array}$ & $\begin{array}{l}\text { Strength of } \\
\text { evidence }\end{array}$ \\
\hline Bedikan et al (1979) & Texas, USA & $\begin{array}{l}\text { Retrospective } \\
\text { observational }\end{array}$ & $\begin{array}{l}73 \text { patients (aged }<40 ; 48 \% \\
\text { men, } 52 \% \text { women) }\end{array}$ & Stomach & Initial misdiagnosis & & & Moderate \\
\hline $\begin{array}{l}\text { Nagao and Takahashi } \\
\text { (1979) }\end{array}$ & Japan & $\begin{array}{l}\text { Retrospective } \\
\text { observational }\end{array}$ & 536 patients & Stomach & Initial misdiagnosis & & & Insufficient \\
\hline MacAdam (1979) & England & $\begin{array}{l}\text { Prospective } \\
\text { observational }\end{array}$ & $\begin{array}{l}\text { I } 50 \text { patients ( } 21 \% \text { with } \\
\text { stomach cancer), I05 GPs }\end{array}$ & Stomach & & Cancer site - stomach & $\begin{array}{l}\text { Regular } \\
\text { consulting rate } \\
\text { of patient }\end{array}$ & Moderate \\
\hline Ojala et al (1982) & Finland & $\begin{array}{l}\text { Retrospective } \\
\text { observational }\end{array}$ & $\begin{array}{l}\text { I62 patients (aged } 38-82 \\
\text { mean } 63 ; 59 \% \text { men, } 41 \% \\
\text { women) }\end{array}$ & Oesophagus & Initial misdiagnosis & & & Insufficient \\
\hline $\begin{array}{l}\text { Mikulin and Hardcastle } \\
\text { (1987) }\end{array}$ & England & $\begin{array}{l}\text { Prospective } \\
\text { observational }\end{array}$ & $\begin{array}{l}83 \text { patients (mean } 71 ; 64 \% \\
\text { men, } 36 \% \text { women) }\end{array}$ & Stomach & $\begin{array}{l}\text { Acid suppression } \\
\text { treatment; patient age - } \\
\text { younger }\end{array}$ & $\begin{array}{l}\text { Patient age - older; patient } \\
\text { social class - lower }\end{array}$ & & Moderate \\
\hline Zilling et al (1990) & Sweden & $\begin{array}{l}\text { Prospective } \\
\text { observational }\end{array}$ & $\begin{array}{l}50 \text { patients (aged } 31-85 \text {, } \\
\text { mean } 68 ; 74 \% \text { men, } 26 \% \\
\text { women) }\end{array}$ & Stomach & $\begin{array}{l}\text { Patient sex - female; } \\
\text { comorbidity; previously } \\
\text { negative results }\end{array}$ & Patient sex - male & & Strong \\
\hline Hallissey et al (1990) & England & Cohort & $\begin{array}{l}2585 \text { patients with dyspepsia } \\
\text { (aged } 40+\text { ) }\end{array}$ & Stomach & Initial misdiagnosis & & & Insufficient \\
\hline $\begin{array}{l}\text { Haugstvedt et al } \\
\text { (199|) }\end{array}$ & Norway & $\begin{array}{l}\text { Prospective } \\
\text { observational }\end{array}$ & I 65 patients & Stomach & Patient sex - female & $\begin{array}{l}\text { Referral to university } \\
\text { hospital }\end{array}$ & & Moderate \\
\hline Maglinte et al (1991) & Indiana, USA & $\begin{array}{l}\text { Prospective } \\
\text { observational }\end{array}$ & $\begin{array}{l}77 \text { patients (aged } 30-89 \text {, } \\
\text { mean 59; } 64 \% \text { men, 36\% } \\
\text { women }\end{array}$ & Small intestine & Inappropriate tests & & & Moderate \\
\hline $\begin{array}{l}\text { Jones and Dudgeon } \\
\text { (1992) }\end{array}$ & England & $\begin{array}{l}\text { Retrospective } \\
\text { observational }\end{array}$ & $\begin{array}{l}245 \text { GPs, I } 465 \text { patients } \\
\text { (> } 60 \text { with upper Gl cancer) }\end{array}$ & $\begin{array}{l}\text { Oesophagus, } \\
\text { stomach }\end{array}$ & Cancer site - oesophagus & & & Moderate \\
\hline $\begin{array}{l}\text { Arvanitakis et al } \\
\text { (1992) }\end{array}$ & Greece & Observational & $\begin{array}{l}100 \text { patients (aged } 40-90 \\
64 \% \text { men, } 36 \% \text { women) }\end{array}$ & Stomach & Initial misdiagnosis & & & Insufficient \\
\hline Wile et al (1993) & $\begin{array}{l}\text { California, } \\
\text { USA }\end{array}$ & $\begin{array}{l}\text { Retrospective } \\
\text { observational }\end{array}$ & $\begin{array}{l}49 \text { patients (median } 57 ; 45 \% \\
\text { men, } 55 \% \text { women) }\end{array}$ & Stomach & Inaccurate tests & & & Strong \\
\hline Martin et al (1997) & England & $\begin{array}{l}\text { Prospective } \\
\text { observational }\end{array}$ & $\begin{array}{l}\text { II } 5 \text { patients (aged } 31-89 \\
\text { median } 66 ; 61 \% \text { men, } 39 \% \\
\text { women) }\end{array}$ & $\begin{array}{l}\text { Oesophagus, } \\
\text { stomach }\end{array}$ & $\begin{array}{l}\text { Frequent attendance by } \\
\text { patient; cancer site - } \\
\text { oesophagus }\end{array}$ & $\begin{array}{l}\text { Access to rapid screening } \\
\text { (open access endoscopy) }\end{array}$ & Initial symptom & Insufficient \\
\hline Rothwell et al (1997) & Ireland & $\begin{array}{l}\text { Prospective } \\
\text { observational }\end{array}$ & $\begin{array}{l}\text { I00 patients (aged } 37-83 \\
\text { median } 69 ; 70 \% \text { men, } 30 \% \\
\text { women) }\end{array}$ & Oesophagus & $\begin{array}{l}\text { Acid suppression } \\
\text { treatment; initial } \\
\text { misdiagnosis; inappropriate } \\
\text { tests }\end{array}$ & & & Moderate \\
\hline Bramble et al (2000) & England & $\begin{array}{l}\text { Retrospective } \\
\text { observational }\end{array}$ & $\begin{array}{l}\text { I } 33 \text { patients (aged } 38-97 \\
\text { mean } 69 ; 53 \% \text { men, } 47 \% \\
\text { women) }\end{array}$ & $\begin{array}{l}\text { Oesophagus, } \\
\text { stomach }\end{array}$ & $\begin{array}{l}\text { Acid suppression } \\
\text { treatment }\end{array}$ & & & Strong \\
\hline Mariscal et al (200I) & Spain & $\begin{array}{l}\text { Prospective } \\
\text { observational }\end{array}$ & $\begin{array}{l}217 \text { patients (aged } 59-74 \text {, } \\
\text { mean } 65 ; 59 \% \text { men, } 41 \% \\
\text { women), } 27 \% \text { with upper Gl } \\
\text { cancer }\end{array}$ & $\begin{array}{l}\text { Oesophagus, } \\
\text { stomach }\end{array}$ & & $\begin{array}{l}\text { Comorbidity; symptom } \\
\text { type - pain, bleeding }\end{array}$ & & Strong \\
\hline Irving et al (2002) & England & Observational & $\begin{array}{l}90 \text { patients ( } 72 \% \text { with } \\
\text { oesophageal, } 28 \% \text { with } \\
\text { gastric) }\end{array}$ & $\begin{array}{l}\text { Oesophagus, } \\
\text { stomach }\end{array}$ & & $\begin{array}{l}\text { Use of referral guidelines; } \\
\text { 2-week rule }\end{array}$ & & Strong \\
\hline Manes et al (2002) & Italy & Cross-sectional & $\begin{array}{l}706 \text { endoscopy referrals } \\
\text { (aged I5-86, mean } 47 ; 55 \% \\
\text { men, } 45 \% \text { women) }\end{array}$ & Stomach & $\begin{array}{l}\text { Inappropriate use of } \\
\text { endoscopy }\end{array}$ & & & Strong \\
\hline Look et al (2003) & Singapore & $\begin{array}{l}\text { Retrospective } \\
\text { observational }\end{array}$ & $\begin{array}{l}44 \text { patients (aged } 36-83 \text {, } \\
\text { mean } 67 ; 70 \% \text { men, } 30 \% \\
\text { women) }\end{array}$ & Stomach & Previously negative results & & & Moderate \\
\hline
\end{tabular}

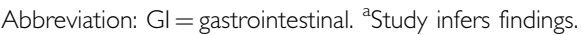

coexisting disease or frequent patient attendance was inconclusive, referral was more likely to be delayed if the patient was being treated for a benign condition. Delays were also demonstrated where patients had already been investigated for the same or similar symptoms and had previous negative test results. Whilst it is undoubtedly appropriate for practitioners to consider past history when considering new symptoms or diagnoses, this does raise the question of when a negative test result should be considered to be no longer of relevance.

\section{Patient characteristics}

The potential for individual patient characteristics to impact on delay was considered, to some extent, in the included studies, and analysis of these suggests that lower socio-economic status increases delay, whereas sex has no impact. However, there remains a dearth of evidence relating to why some patients respond to early warning signs or unusual symptoms, whilst, others do not. Accordingly, there is a prevailing need to understand the impact of social and psychological factors on patient behaviour. Many studies focused on the appropriateness of patient response to symptoms, yet only a minority attempted to explore the reasons for this, and then primarily from a psychological perspective. Few have done so from a social perspective. As a consequence, there is little conclusive evidence relating to the influence brought to bear by age, level of education or social network. Yet if we consider that new symptoms occur, not in isolation, but in the context of an individual's life circumstances, 
it is likely that investigations of social factors will yield valuable insights in this area.

Although only a limited number of patient characteristics were considered in relation to practitioner referral behaviour, there was some evidence to suggest that younger and female patients experienced increased delays. Conversely, patients from lower socio-economic groups were less likely to experience delay. This is in direct contrast to the impact of socio-economic status on patient delay, and it could be postulated that as these patients have already delayed prior to their initial presentation, the need for rapid referral is all the more apparent.

\section{Health-care factors}

Several recent policy initiatives have been directed at the practitioner phase of delay, and the results of this review suggests that these may be starting to have an impact. An evaluation of outcomes related to the introduction of standardised referral guidelines in the UK demonstrated positive effects on delay. Similarly, a relationship between provision of services and reduced delay has also been shown, with those patients who have use of a rapid access endoscopy service experiencing less delay in referral. However, the evidence in this regard is as yet inconclusive, and it had been suggested that inappropriate use of such a service could increase delay as a consequence of an increased volume of referrals. As yet, only a few studies have explored these initiatives in detail, and although those that have done so indicate that they are, for the most part, successful, further work will enable more definitive conclusions to be drawn.

\section{Implications for practitioners}

Many of the studies in this review reported practitioner misdiagnosis as a significant contributor to delay. The studies were not designed in a way that would allow the observer to assess the nature of that 'misdiagnosis'. However, it is clear that there are significant challenges for practitioners in assessing symptoms such as dyspepsia, including evaluation in the context of acid suppression therapy, and previous negative test results. Such issues need to be clearly addressed within guidelines.

\section{REFERENCES}

Arvanitakis C, Nikopoulos A, Giannoulis E, Theoharidis A, Georgilas V, Fotiou H (1992) The impact of early or late diagnosis on patient survival in gastric cancer in Greece. Hepato-Gastroenterology 39: 355-357

Bedikan AY, Khankhanian N, Helibrun LK, Bodey GP, Stroehlein JR, Valdivieso M (1979) Gastric carcinoma in young adults. Southern Med J 72(6): $654-656$

Bramble MG, Suvakovic Z, Hungin APS (2000) Detection of upper gastrointestinal cancer in patients taking antisecretory therapy prior to diagnosis. Gut 46(4): 464-467

Delaney BC (1998) Why do dyspeptic patients over the age of 50 consult their general practitioner? A qualitative investigation of health beliefs relating to dyspepsia. Br J Gen Pract 48: 1481-1485

Department of Health (2000) Referral Guidelines for Suspected Cancer. London: $\mathrm{DoH}$

Grannell MS, Kelly S, Shannon S, Chong AL, Walsh TN (2001) The sinister significance of dysphagia. Irish J Med Sci 170(4): 244-245

Gullo L, Tomassetti P, Migliori M Casadei R, Marrano R (2001) Do early symptoms of pancreatic cancer exist that can allow for an earlier diagnosis? Pancreas 22(2): 210-213

Hackett TP, Cassem NH, Raker JN (1973) Patient delay in cancer. New Engl J Med 289(1): $14-20$

Hallissey MT, Allum WH, Jewkes AJ, Ellis DJ, Fielding JWL (1990) Early detection of gastric cancer. BMJ 301: 513-515

Haugstvedt TK, Viste A, Eide GE, Soreide O (1991) Patient and physician treatment delay in patients with stomach cancer in Norway: is it important? Scand J Gastroenterol 26(6): 611-619

\section{Implications for research}

One of the most surprising findings of this review is that although the majority of studies reported on primary care practitioner delay, only two of these involved primary care practitioners as participants and only three recruited patients from primary care. Most were conducted in secondary care and consisted of a series of either prospective or retrospective clinic experiences. Furthermore, in those studies involving practitioners, the participants were primary care doctors. Consequently, the contribution that may be made by other health-care practitioners, such as nurses, has not yet been investigated.

Ramirez et al (1999), in their review of factors predicting delayed presentation with breast cancer, highlighted the need for further research into understanding delay in order to impact on presentation behaviour. Although some work has been commissioned since their call for it, it is clear that we still lack understanding of this area. This review demonstrates the complex nature of delay and consequently, the difficulty of devising strategies to reduce it. However, this must be achieved if the ultimate aim of improving survival is to be met. Influencing this is likely to involve gaining greater appreciation of the impact of patient characteristics, alongside development of strategies to aid practitioners in assessing GI symptoms.

\section{ACKNOWLEDGEMENTS}

We acknowledge the support of Michere Beaumont, Catherine McNeill (Research Secretaries), Jane Goodfellow (Dissemination and Information Officer) and Madeline Young (Subject Librarian), University of Glasgow in carrying out this project. We would also thank David Mant for his input into this project, Joan Austoker (University of Oxford) for help in identifying international contacts and Jolanta Astle, Simon Browne, Yulia Gaidakova, Karen Kane, Marina Novikova, Gaby Vojt and Phil Wilson for translation of non-English language articles. Finally, we would thank the authors, cancer leads and other contacts who responded to our request for relevant work. This study was funded by the UK DoH (project reference 1217522).
Ibingira CBR (2001) Management of cancer of the stomach in Mulago hospital, Kampala, Uganda. East Afr Med J 78(5): 233-237

Irving MJ, Lamb PJ, Irving RJ, Raimes SA (2002) Speeding up the diagnosis of oesophago-gastric cancer. Nurs Times 98(51): 35-37

Jones RVH, Dudgeon TA (1992) Time between presentation and treatment of 6 common cancers: a study in Devon. Br J Gen Pract 42: 419-422

Look M, Tan YY, Vijayan A, Teh CH, Low CH (2003) Management delays for early gastric cancer in a country without mass screening. HepatoGastroenterology 50: $873-876$

Love N (1991) Why patients delay seeking care for cancer symptoms. What you can do about it. Postgrad Med 89: $151-158$

MacAdam DB (1979) A study in general practice of the symptoms and delay patterns in the diagnosis of gastrointestinal cancer. J R College Gen Pract 29: $723-729$

Macdonald S, Macleod U, Mitchell E, Weller D, Campbell N, Mant D (2004) Factors influencing patient and primary care delay in the diagnosis of cancer: a database of existing research and its implications for future practice. Final report to the UK Department of Health Glasgow: University of Glasgow

Maglinte DDT, O’Connor K, Besette J, Chernish SM, Kelvin FM (1991) The role of the physician in the late diagnosis of primary malignant tumours of the small intestine. Am J Gastroenterol 86(3): 304-308

Manes G, Balzano A, Marone P, Lionello M, Mosca S (2002) Appropriateness and diagnostic yield of upper gastrointestinal endoscopy in an open access endoscopy system: a prospective observational study based on the Maastricht guidelines. Alimentary Pharmacol Therapeut 16: 105-110 
Mariscal M, Llorca J, Prietd D, Delgado-Rodriguez M (2001) Determinants of the interval between the onset of symptoms and diagnosis in patients with digestive tract cancers. Cancer Detect Prevent 25(5): 420 - 429

Martin IG, Young S, Sue-Ling H, Johnson D (1997) Delays in the diagnosis of oesophagastric cancer: a consecutive case series. BMJ 314: $467-470$

Mikulin T, Hardcastle JD (1987) Gastric cancer - delay in diagnosis and its causes. Eur J CancerClin Oncol 23(11): 1683-1690

Mitchell E, Sullivan F (2001) A descriptive feast but an evaluative famine: systematic review of published articles on primary care computing during 1980-97. BMJ 322: 79-82

Nagao F, Takahashi N (1979) Diagnosis of advanced gastric cancer. World J Surg 3: $693-700$

National Institute for Health and Clinical Excellence (2005) Referral Guidelines for Suspected Cancer: Clinical Guideline 27. London: NICE

Nichols S, Waters WE, Fraser JD, Wheeller MJ, Ingham SK (1981) Delay in the presentation of breast symptoms for consultant investigation. Commun Med 3: 217-225

Ojala K, Sorri M, Jokinen K, Kariluoma M (1982) Symptoms of carcinoma of the oesophagus. Med J Austr 1(9): 384-385

Pack GT, Gallo JS (1938) The culpability for delay in the treatment of cancer. Am J Cancer 33: 443-462

\section{Appendix A1}

\section{Scoring system - experimental studies}

(Randomised controlled trials/case-controlled trials/controlled before and after studies)
Ponten J, Adami HQ, Bergstrom R, Dilner J, Friberg LG, Gustafsson L, Miller AB, Parkin DM, Sparen P, Trichopoulos D (1995) Strategies for global control of cervical cancer. Int J Cancer 60(1): 1-26

Porta M, Gallen M, Belloc J, Malats N (1996) Predictors of the interval between the onset of symptoms and first medical visit in patients with digestive tract cancer. Int J Oncol 8: 941-949

Ramirez AJ, Westcombe AM, Burgess CC, Sutton S, Littlejohns P, Richards MA (1999) Factors predicting delayed presentation of symptomatic breast cancer: a systematic review. Lancet 353: 1127-1131

Richards MA, Westcombe AM, Love SB, Littlejohns P, Ramirez AJ (1999) Influence of delay on survival in patients with breast cancer: a systematic review. Lancet 353: 1119-1126

Rothwell JF, Feehan E, Reid I, Walsh TN, Hennessy TPJ (1997) Delay in treatment for oesophageal cancer. Br J Surg 84(5): 690-693

Summerton N (1999) Diagnosing Cancer in Primary Care. Oxford: Radcliffe Medical Press

Wile AG, Hourani L, Schell MJ (1993) The contribution of patient factors, physician delay and tumour biology to the outcome of gastric cancer. Am Surgeon 59(12): $850-854$

Zilling TL, Walther BS, Ahren B (1990) Delay in diagnosis of gastric cancer: a prospective study evaluating doctors' and patients' delay and its influence on five year survival. Anticancer Res 10: 411-416

\section{Notes}

\footnotetext{
Sample formation

2 - Random

I - Quasi random

0 - Selected, concurrent or historical
}

Baseline differences

2 - None or adjusted

I - Differences unadjusted

0 - No statement

N.B. This is the difference between groups providing the unit of analysis

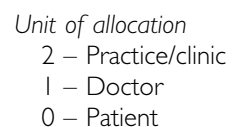

\section{Outcome measures}

2 - Objective/subjective with assessors blinded

I - Subjective, assessors not blinded, explicit criteria given

\section{0 - Subjective, assessors not blinded, no explicit criteria}

$$
\begin{aligned}
& \text { Follow-up } \\
& \qquad \begin{array}{l}
2->90 \% \text { subjects starting study } \\
1-80-90 \% \text { subjects starting study } \\
0-<80 \% \text { subjects starting study }
\end{array}
\end{aligned}
$$

N.B. This relates to subjects accounted for at the end of the study, not just those with a positive outcome.
For example, stratification

Randomised by toss of coin - I

- Group members acting as both intervention and control (if randomised) - I

- Subjects chosen

Mentioned but not specified (e.g. no difference) - ।

Nothing of note

Questionnaires -

Mentions 'eligible' patients but does not specify what eligible is (open to interpretation) - I (or based on scores etc.)

- Mentions that outcomes may be under/over estimated

Is information provided to verify that researchers know that all subjects were contacted

Exclude from follow-up calculation:

- Subjects excluded from analysis

- Non-responders in questionnaire surveys

- If there is no statement about follow-up or conclusive information in tables (e.g. baseline $n=\ldots$; follow-up $n=\ldots$ ) do not calculate. Follow-up $=$ unable to determine 


\section{Appendix B1}

Scoring system - descriptive studies

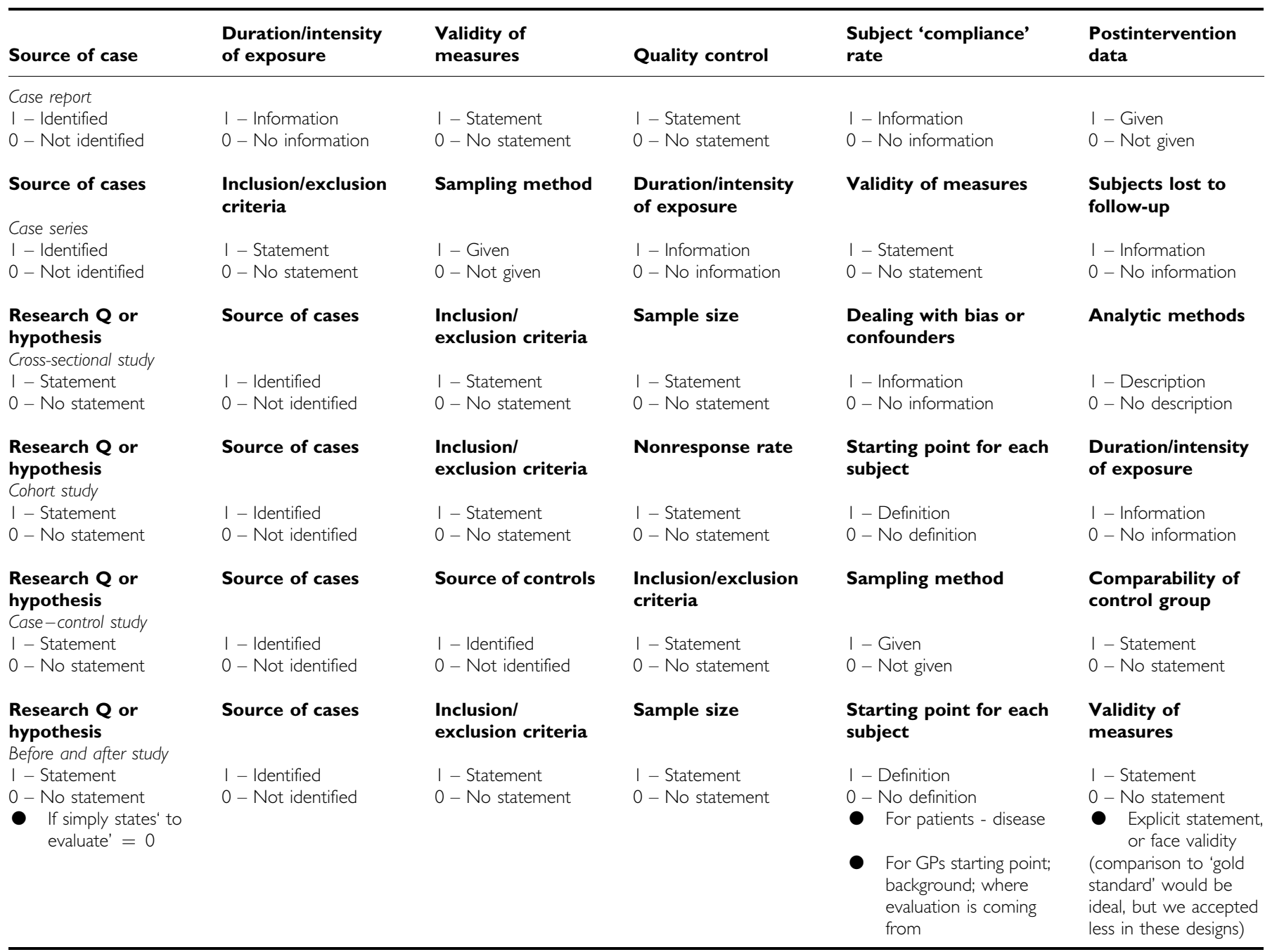

